\title{
STAGNATION, DECLINE, AND DEVELOPMENT: A TRIP THROUGH THE SOUTHERN COUNTRYSIDE (1992 Fellow's Address)
}

\author{
William A. Schaffer*
}

\begin{abstract}
Based on the 1992 Fellow's Address of the Southem Regional Science Association, this article takes a nostalgic tour through Georgia's rural countryside, showing the effects of stagnation and decline. It then reviews the conditions for growth and development in the tradition of Schumpeter and Ricardo, their applicability to the rural South, and their implications for regional scientists.
\end{abstract}

\section{INTRODUCTION}

Thank you very much for bestowing upon me the great honor of Fellow of the Southem Regional Science Association. The Association is a wonderful organization, dear to my heart. We have grown up together, and from it I have gained my most valued professional friends.

In renewing my commitment to our region and its development, I would like to take you on a trip through the Southern countryside before making the enudite observations that this occasion demands.

\section{STAGNATION AND DECLINE}

I take my inspiration from an experience just last Sunday. I went to church with my mother. Our church is a quaint little place, Mt. Zion, at the site of what was once Mechanicsville, our "home place" in Jasper County, Georgia. The church is unlit and unheated, to our knowledge the last such in Georgia. The window glass shows the distortions of old rolled panes. We stuff pegs beneath the piano pedals after every service to keep out the mice. The faded cardboard fans for summer are compliments of the Monticello Funeral Home. The songbooks were a gift from my grandmother more than 50 years ago. The meadowlark punctuates the preacher's sermon.

Of the 40-odd people in attendance, less than five live within two miles. My 80-year-old mother is the last member, the next-to-last having died last fall. She

\footnotetext{
*Professor, School of Economics, Georgia Institute of Technology, Atlanta, Georgia. This paper was adapted from the Fellow's Address at the 1992 Meeting of the Southem Regional Science Association in Charleston, South Carolina.
} 
lives in Atlanta but faithfully acts as secretary-treasurer, having inherited the position from her mother. We hold services on fifth Sundays, except in summer when it is too hot and in winter when it is too cold. There were two services last year, which is just about right for a backsliding economist. But each service is a great affair: plenty of singing (sometimes repeated standing when not loud enough), a couple of good prayers, and a nice, compact, 15-minute sermon. Afterwards, we pull the benches back, take the table tops from behind the pulpit, screw in the legs made from pipe, and enjoy a wonderful meal made from Granny's old receipes.

Mother and I salute our ancestors on the way out. Pop, my grandfather, was the last to be buried in the family plot in the sixties. The grass still does not cover the center of his grave where the harsh red clay peeks through, defying us.

Then we drive down the dirt road toward Monticello. Past the site of the cotton gin that I helped Pop disassemble as a boy. Past the home place where Mother was raised in sight of the church, which is now a deer hunting club house all in shambles. Past home after home fallen to ruins. Past the old chimneys left from Sherman's March to the Sea during the war. Past occasional large dairy farms and a few plowed fields. Finally we pass the site of my raising, now weed-covered, but with the pecan trees and the old poplar tree still standing.

We pass the Dairy Queen and the motel and a little shopping center, all marring my recollection of wonderful rides to school on my "victory" bike.

We circle the square, once covered with great oaks shading the obligatory Confederate obelisk, now ringed with fast-growing pear trees. ("Diseased and dying," my friends say of the oaks. "The limbs were falling on people.")

We salute the courthouse, where my wife, Lee, and I were married, and where so many grand old philosophers once held court on the steps. Incidentally, the movie "Our Cousin Vinny" was filmed in Monticello. I have not seen the movie yet, but the advertisements provide some great shots of the courthouse. You can see the clock up in the dome-sneaking up inside to see the clockworks was a rite of passage in my time. My friends tell me that the movie people didn't change a thing to make the town look older and dilapidated, like a rural Alabama town should be. They did reconstruct the courtroom in the studio to get better camera angles, but they were careful to build the "old" into the set. Alabama people, they say, are complaining: Alabama gets the blame, and Georgia gets the money.

Anyway, we circle the square again and take off up the street over "white hill"-past the great mansions and out to the plywood plant and the trailer axle plant. We return through "black hill" on now-paved streets.

We drive past the site of the Monticello Bobbin Mill, which the owner closed and burned in protest of OSHA regulations that he thought a tad excessive. My first economic impact study was of that mill in 1950 , when I won the $\$ 50$ first 
prize in an essay contest. I did not know then that I would spend much of my adult life doing more such studies.

We go back through town. Too many trees gone. Too much paint peeling. Too many new ramshackle buildings jammed into awkward positions, marring the beauty of a once orderly central place town, complete with the required six highways connecting to higher and lesser ordered towns. (The lesser ordered towns are rapidly disappearing. Mechanicsville went with the boll weevil, Farrar went with the general store, Machen and Shady Dale barely survive. Juliette was awarded a brief reprieve when "Fried Green Tomatoes" was filmed there-folks there are so excited that they are going to open a restaurant again to feed all of the tourists!)

In my youth, I never dreamed that Monticello would come to this. Miss Mary, my favorite history teacher, said it would, but what did she know? She said that the farms could not hold the people, that the factories would come, that gentility would vanish, that Monticello would become just another mill town. She knew then that the town would decay as the more educated and mobile people left. She knew that life required more than mass production and money.

I left early. My uncle said that we were fortunate-our parents owned no store and no great farm. We could leave with no obligations to the land. But I left thinking that I could go away, become educated, retum, and make a difference.

I was wrong-I never came back, and I could not have made a difference. I was limited in my vision. I thought we could hold on to this little town of 2,000, with tree-lined streets, neatly swept sidewalks, well-kept buildings, educated people, good homes, and schools and families closely tied in strong community. I didn't realize how hard it is to maintain a proper balance between growth and development.

\section{GROWTH AND DEVELOPMENT}

This thought leads me to the topic on which I must close, a topic almost universally chosen by speakers at this forum: regional growth and development.

Growth is always identified as the less desirable of the two. Several years ago, Hugh Knox (1987) described it as expansion-just more of the same. Many years ago, in his famous Theory of Economic Development, Joseph Schumpeter (1959), in a slightly more generous mood, listed three conditions for growth. The first is that profitable opportunities must exist. Growth requires situations in which the value of outputs exceeds that of inputs, otherwise there would be no source of capital accumulation and no incentive to change. The primary source of 
such opportunities is innovation, or technical change. In rural regions, with agriculture past its high growth point, these opportunities come from the outside.

The second condition of growth is the availability of entrepreneurs to exploit these opportunities. Here, the sparsely populated trade-and-agriculture-oriented rural regions are also at a disadvantage. In modem times, with economies of scale and technology becoming increasingly important, the small entrepreneur without a technical education is finding it difficult to compete. And the entrepreneurship is frequently institutionalized within the firms bringing branch plants to our towns.

The third condition is the availabilitiy of capital for use in this exploitation of opportunities. Rural banks now often act as collectors for the large city banks and have ceased to perform as community builders.

These conditions work against hometowns like mine. Profitable opportunities exist for footloose firms eager to exploit the remaining poorly educated and immobile work force. The potential entrepreneurs migrate to seek education and their fortunes in larger cities. And capital is sucked out by hungry megabanks with little concern for marginal opportunities in the hinterlands. To me, growth at the hands of outsiders seems a likely fate for our little towns.

Economic development is a broader concept than growth. Schumpeter described it as including "only such changes in economic life as are not forced upon it from without but arise by its own initiative, from within" $(1959,63)$. It involves structural changes within the system that are not necessary under conditions of growth. With growth, we are primarily concerned with nonstructural changes, which are frequently in response to outside stimuli.

As regional scientists, you and I clearly embrace "economic development" as the desired state for a region. As Southern regional scientists, you probably join me in being as much place-oriented as discipline-oriented.

What are we to do to help our places? In discussing countries with great resources but poor people, David Ricardo said in 1817 that this "... evil proceeds from bad government, from the insecurity of property, and from a want of education in all ranks of the people" $(1963,48)$. As citizens and professionals, we must help in every way possible to enhance the education of our people and to prepare them to take new roles in society. We should welcome opportunities to help local governments and organizations in rebuilding the infrastructures of our decaying towns and in handling the increasing problems of negative externalities as growth occurs. We must leave the ivory tower and descend to plow the fields.

Regional scientists are eminently qualified to reach out and help, for we have a long tradition of concem and of willingness to tackle dirty data-filled chores. Please join me in committing to the task of developing our region.

I thank you again for this honor, and I thank you all for making this Association as strong as it has become. From its origins in 1962, through occasionally 
shaky times, it has grown to be a self-sustaining, well-govemed organization. I am proud to be a member.

\section{REFERENCES}

Knox, Hugh W. "The Nonmetropolitan South in the 1990s: Convergence or Stagnation?" Review of Regional Studies 17 (1987): 1-4.

Ricardo, David. The Principles of Political Economy and Taxation. Homewood, III.: Richard D. Irwin, 1963.

Schumpeter, Joseph. The Theory of Economic Development. Translated by Redvers Opie. Cambridge, Mass.: Harvard University Press, 1959. 